\title{
A Case of Cutaneous Spindle Cell Squamous Cell Carcinoma Arising in a Nevus Sebaceous
}

\author{
Yong Woo Oh, Dong Hee Kim, Byeong Hak Seo, Ho Seok Suh, Yu Sung Choi \\ Department of Dermatology, Ulsan University Hospital, University of Ulsan College of Medicine, Ulsan, Korea
}

\section{Dear Editor:}

A 62-year-old female presented with a 4-month history of a rapidly growing dome-shaped nodule on the right side of the face. Physical examination revealed a $1.8 \times 1.5-\mathrm{cm}$, well-demarcated, erythematous, dome-shaped, ulcerated nodule arising within a diffuse, yellow to brown-colored verrucous plaque on the right cheek (Fig. 1). The verrucous plaque had been present since infancy. The patient had no previous relevant medical history, including local trauma, burn, or radiation exposure.

An incisional biopsy of the nodule was performed. Histologic examination revealed aggregates of atypical spindle cells with a fascicular or irregular pattern in the dermis (Fig. 2A). Spindle cells had a large hyperchromatic vesicular nucleus and scanty eosinophilic cytoplasm (Fig. 2B). There was variable pleomorphism with many mitotic figures. An area of epidermal hyperplasia and increased number of sebaceous glands were observed adjacent to the tumor. Immunohistochemical analysis of the spindle cells was positive for cytokeratin (CK) (Fig. 2C), p40 (Fig. 2D), and vimentin (Fig. 2E), but negative for melan-A, HMB-45, S-100, cluster of differentiation (CD) 31, CD34, and desmin. The patient was diagnosed with cutaneous spindle cell squamous cell carcinoma (SpSCC) superimposed on a nevus sebaceous (NS). Computed tomo-

Received May 3, 2019, Revised June 3, 2019, Accepted for publication June 28, 2019

Corresponding author: Yu Sung Choi, Department of Dermatology, Ulsan University Hospital, University of Ulsan College of Medicine, 877 Bangeojinsunhwando-ro, Dong-gu, Ulsan 44033, Korea. Tel: 82-52-250-7090, Fax: 82-52-250-7155, E-mail: uuhderma@daum.net ORCID: https://orcid.org/0000-0001-8308-4091

This is an Open Access article distributed under the terms of the Creative Commons Attribution Non-Commercial License (http://creativecommons. org/licenses/by-nc/4.0) which permits unrestricted non-commercial use, distribution, and reproduction in any medium, provided the original work is properly cited.

Copyright (c) The Korean Dermatological Association and The Korean Society for Investigative Dermatology graphic scan of the brain and ${ }^{99 \mathrm{~m}}$ Technetium bone scintigraphy revealed no evidence of metastasis.

The patient underwent a wide excision with a 10-mm margin from the periphery of the nodule. There has been no evidence of recurrence or metastases during 8 months of follow-up.

Numerous secondary tumors can arise in NS, including syringocystadenoma papilliferum, trichoblastoma, basal cell carcinoma, and squamous cell carcinoma (SCC). The development of an SCC in NS is extremely rare. Our case is an even more unusual variant of SCC (spindle cell) arising in NS. There is only one case report to date ${ }^{1}$.

Cutaneous SpSCC is a rare, aggressive variant of SCC that presents as a raised or exophytic nodule accompanied by bleeding and central ulceration. Generally, SpSCC lesions are associated with sun-damaged skin, burn scar, local trauma, and prior radiation exposure ${ }^{2}$. Histopathologically, SpSCC comprises atypical spindle cells with elongated vesicular nuclei. The presence of squamous differentiation, dyskeratotic cells, and continuity with the epidermis may assist in the diagnosis. However, as these characteristics are not always detected, immunohistochemistry can help distinguish this form from other spindle cell tumors such as atypical fibroxanthoma and dermatofibrosarcoma protuberans. SpSCC cells stain positively for CK, CK5/6, $\mathrm{AE} 1 / 3$, CAM5.2, and vimentin, whereas other nonsquamous spindle cell tumors are negative for $\mathrm{CKs}^{3}$.

Because of its lack of differentiation, SpCC exhibits more aggressive characteristics and accounts for $>33 \%$ of cutaneous metastatic SCC. Typically, malignancies that arise in association with NS are considered non-aggressive lesions. However, sudden growth of a nodular tumor within NS and a large developed nodule as in our patient are regarded as an indication of aggressive behavior ${ }^{4}$.

Herein, we described a case of SpSCC arising within NS. Clinicians should be aware that aggressive malignancies can develop in NS, and early excision should be considered when clinical signs of malignancy are seen, such as 

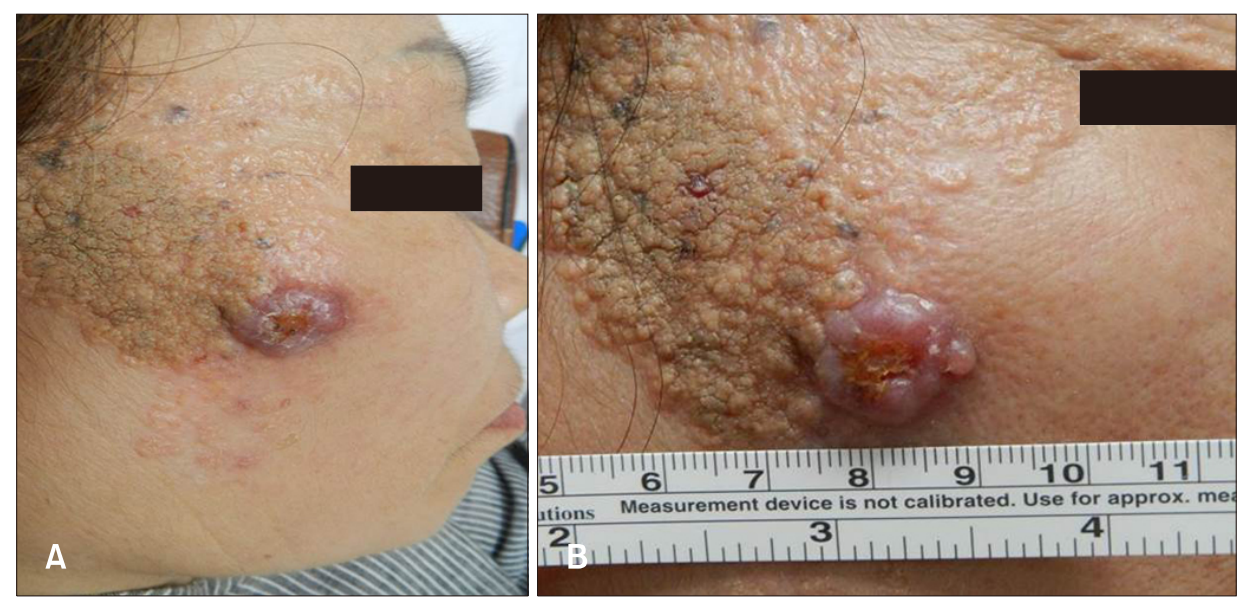

Fig. 1. (A) An erythematous, domeshaped nodule with central ulceration arising in a diffuse, yellow to brown-colored verrucous plaque on the right cheek. (B) Close-up view. We received the patient's consent form about publishing all photographic materials.
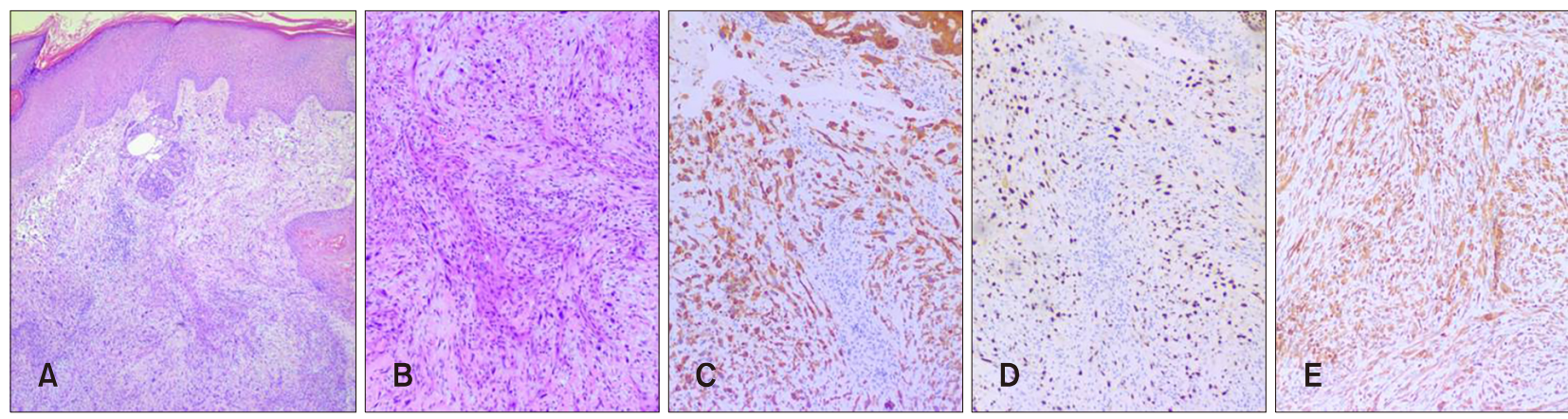

Fig. 2. (A) Aggregates of atypical spindle cells with a fascicular or irregular pattern in the dermis $(H \& E, \times 40)$. (B) The spindle cells have a large hyperchromatic vesicular nucleus and scanty eosinophilic cytoplasm $(\mathrm{H} \& \mathrm{E}, \times 100)$. Immunohistochemical analysis of the spindle cells showed positive for (C) CK $(\times 100)$, (D) p40 $(\times 100)$, and (E) vimentin $(\times 100)$.

rapid nodular growth or ulceration within NS.

\section{CONFLICTS OF INTEREST}

The authors have nothing to disclose.

\section{ORCID}

Yong Woo Oh, https://orcid.org/0000-0001-7169-7798

Dong Hee Kim, https://orcid.org/0000-0002-7727-1429

Byeong Hak Seo, https://orcid.org/0000-0002-7300-8236

Ho Seok Suh, https://orcid.org/0000-0002-6781-5429

Yu Sung Choi, https://orcid.org/0000-0001-8308-4091

\section{REFERENCES}

1. Wu ZW, Shi WM, Sun Y, Li XJ, Song J. Cutaneous spindle cell squamous cell carcinoma in nevus sebaceous. Int $\mathrm{J}$ Dermatol 2010;49:1429-1431.

2. Cassarino DS, Derienzo DP, Barr RJ. Cutaneous squamous cell carcinoma: a comprehensive clinicopathologic classification. Part one. J Cutan Pathol 2006;33:191-206.

3. Morgan MB, Purohit C, Anglin TR. Immunohistochemical distinction of cutaneous spindle cell carcinoma. Am J Dermatopathol 2008;30:228-232.

4. Domingo J, Helwig EB. Malignant neoplasms associated with nevus sebaceus of Jadassohn. J Am Acad Dermatol 1979;1: 545-556. 